lost from the rumen as ammonia, the nitrogen economy of the animal does not suffer from that ammonia loss. If, however, insufficient nitrogen of unsuitable biological value is available to the animal as a result of this process, the portion of the feed escaping digestion by the micro-organisms in the rumen assumes greater importance. This residual food nitrogen reaching the abomasum and intestines is not necessarily that most difficult to digest, because the amount of food eaten by a high-yielding cow may not allow the feed residues to remain in the rumen as long as they might otherwise do. The better the amino-acid composition of the residual feed passing from the rumen, the better the biological value of the total feed.

The most desirable type of feed protein for a ruminant is, therefore, one of reasonably low solubility in the rumen yet of high biological value for the singlestomached animal.

These arguments must be taken a stage further for application to agricultural practice because, although this thesis has been supported by experimental evidence, there are two further points which need consideration: ( $I$ ) is the cow normally rationed sufficiently tightly for protein for any of these theoretical improvements to become evident, and (2) may it not be more economical to give a theoretically wasteful protein source if it still supplies cheaper units of biological value?

\title{
REFERENCES
}

Annison, E. F., Chalmers, M. I., Marshall, S. B. M. \& Synge, R. L. M. (1954). F. agric. Sci. 44, 270. Chalmers, M. I. \& Synge, R. L. M. (1954). F. agric. Sci. 44, 263.

Chalmers, M. I., Cuthbertson, D. P. \& Synge, R. L. M. (1954) F. agric. Sci. 44, 254.

Fontaine, T. D., Samuels, C. \& Irving, G. W. Jr. (1944). Industr. Engng Chem. (Industr.) 36, 625.

Head, M. J. (I953). F. agric. Sci. 43, 281 .

Head, M. J. \& Rook, J. A. F. (I957). Proc. Nutr. Soc. I6, 25.

Johnson, B. C., Hamilton, T. S., Mitchell, H. H. \& Robinson, W. B. (1942). J. Anim, Sci, 1, 236.

Lewis, D. (1957). F. agric. Sci. $48,438$.

McDonald, I. W. (1948). Biochem. F. 42, 584 .

McDonald, I. W. (1952). Biochem. F. 51, 86 .

McDonald, I. W. \& Hall, R. J. (1957). Biochem. F. 67, 400.

McNaught, M. L., Smith, J. A. B., Henry, K. M. \& Kon, S. K. (1950). Biochem. F. 46, 32.

Williams, V. J. \& Moir, R. J. (195I). Aust. F. sci. Res. Ser. B, 4, 377.

\section{Lipids in relation to rumen function}

\section{By G. A. Garton, Rowett Research Institute, Bucksburn, Aberdeen}

The term lipids can be taken to include, inter alia, all fatty acids both in the free state and in their esterified forms. However, for the purpose of this Symposium, the formation of the water-soluble, steam-volatile fatty acids that result from the bacterial breakdown of carbohydrates and amino acids in the rumen will not be discussed. Nevertheless, it should be mentioned that the acetate absorbed from the rumen probably plays an important part in the synthesis of higher fatty acids which contribute to the formation of depot and milk glycerides. Further, the occurrence in ruminant body and milk lipids of small amounts of branched-chain, higher fatty acids and of $n$-fatty acids containing an odd number of carbon atoms is probably the 
result of the condensation of branched-chain, volatile acids (e.g. isovaleric and 2methylbutyric acids) and of propionate, respectively, with acetic-acid units (for review see Shorland, I955).

The main topic to be discussed, that of the fate of dietary lipids in the adult ruminant, is preceded by a consideration of the nature of these lipids and is followed by an account of the nature of the lipids of rumen bacteria.

\section{Dietary lipids}

A large part of the diet of adult ruminants, both in the wild state and when domesticated, is derived from herbage, especially from leaves. Of particular importance in this respect are the leaves of grasses, the dry matter of which contains $4-6 \%$ of lipids made up of glycerides $I^{\cdot} 5^{-4} \cdot 4^{\circ}$, waxes $0.5^{-1} \cdot 0$, sterols $0.5^{-1} \cdot 0$, and phospholipids together with salts of phosphatidic acid $0.5-1 \cdot 0 \%$ (see Hilditch, I956). The bulk of the fatty acids in the ingested grass is thus in glyceride combination; examples of analyses typifying the nature of these fatty acids are given in Table $\mathrm{I}$, which shows the remarkable extent to which $\mathrm{C}_{18}$ unsaturated components contribute to the total, with the tri-unsaturated linolenic acid predominating.

\section{Table I. Fatty-acid composition of pasture triglycerides}

(Data referring to cocksfoot grass from Shorland (1944) and to mixed pasture grasses from Hilditch (1956), citing unpublished observations of Jasperson \& Burke)

\begin{tabular}{|c|c|c|}
\hline & Percentage by $w$ & al fatty acids \\
\hline Fatty acid & $\begin{array}{l}\text { Cocksfoot grass } \\
\text { (Dactylis glomerata) }\end{array}$ & $\begin{array}{l}\text { Mixed pasture } \\
\text { grasses }\end{array}$ \\
\hline Saturated: & & \\
\hline Lauric & - & $2 \cdot 9$ \\
\hline Myristic & I. 4 & $3 \cdot 3$ \\
\hline Palmitic & II $\cdot 2$ & $9 \cdot 4$ \\
\hline Stearic & $2 \cdot 6$ & $\mathrm{r} \cdot 5$ \\
\hline Higher than $\mathrm{C}_{18}$ & $1 \cdot 5$ & 0.7 \\
\hline Unsaturated: & & \\
\hline $\mathrm{C}_{12}$ & - & 0.3 \\
\hline Myristoleic & 0.4 & 0.4 \\
\hline Palmitoleic & $6 \cdot 4$ & $3 \cdot 0$ \\
\hline $\mathrm{C}_{18}$ & $76 \cdot 5^{*}$ & $78 \cdot 5^{*}$ \\
\hline
\end{tabular}

${ }^{*}$ Comprising about $50 \%$ as linolenic acid, $\mathbf{1}_{5-25} \%$ as linoleic acid and the remainder as oleic acid.

Domesticated species also ingest the lipids present in such feeding-stuffs as hay, artificially dried grass, silage, concentrates (of both vegetable and animal origin) and roots. The lipids of hay and dried grass will, of course, resemble those of pasture grasses, though it is possible that some oxidative changes occur in the component unsaturated fatty acids during drying and storage. With legume-grass silages it is of interest to note that Ward \& Allen (I957) found that, on a dry-matter basis, they were at least as rich in linoleic and linolenic acids as were mixtures of fresh leguminous plants and grasses. The lipid content of concentrates depends upon their origin and on other factors, such as whether or not they have been solvent-extracted; in the most commonly used plant materials (e.g. maize meal, linseed meal, groundnut 
meal, wheat brans, barley, oats) the oil present contains glycerides rich in $\mathrm{C}_{18}$ unsaturated fatty acids, whereas in such animal products as fish meals it is likely that unsaturated acids of longer chain length are present in the lipids.

The amount of dietary lipids consumed by herbivorous animals is not as insignificant as it is sometimes assumed to be. Though no precise information appears to be available, it can readily be calculated, on the assumption that the dry-matter content of the grass is $20 \%$ and that triglycerides constitute $4 \%$ of the dry matter, that, for example, a cow eating $100 \mathrm{lb}$ grass in a day will thereby ingest $360 \mathrm{~g}$ of glycerides. Even greater amounts of lipids are frequently contained in the rations given to milking cows under conditions of stall feeding.

\section{The fate of dietary lipids in the rumen}

Hydrogenation of unsaturated fatty acids. Attention was first drawn to the influence of the rumen on lipids by Reiser ( $195 \mathrm{I}$ ), who found that when linseed oil was incubated in vitro with sheep rumen contents a marked reduction in the linolenicacid content of the oil took place, which was attributed to partial hydrogenation by the rumen bacteria. Subsequently Reiser and his associates fed steers on a diet containing $5 \%$ cottonseed oil and found that the depot fat of the animals had a higher content of saturated acids and a lower content of oleic acid than that of control animals which received the basal low-fat diet only; this finding was ascribed to hydrogenation of the unsaturated acids of the cottonseed oil in the rumen (Willey, Riggs, Colby, Butler \& Reiser, 1952). These observations were corroborated by Reiser \& Reddy (1956) who for I I weeks fed goats on a diet containing 10\% cottonseed oil or 10\% linseed oil. At slaughter, $6 \mathrm{~h}$ after the last feed, samples of the fatty acids present in the rumen were obtained after saponification of portions of the contents. Determinations of iodine value showed that extensive hydrogenation of the fatty acids of the ingested lipids had taken place; these results, together with other similar findings for sheep, are shown in Table 2.

In the work of Shorland, Weenink \& Johns (I955), referred to in Table 2, fattyacid analyses revealed that linolenic acid was particularly effectively hydrogenated-

Table 2. Iodine values of fatty acids of dietary lipids and of lipids of rumen contents

\begin{tabular}{|c|c|c|c|c|}
\hline \multirow{3}{*}{$\begin{array}{l}\text { Animal } \\
\text { Goat: I }\end{array}$} & \multirow[b]{2}{*}{ Diet } & \multicolumn{2}{|c|}{ Iodine value of fatty acids } & \multirow[b]{2}{*}{ Reference } \\
\hline & & Dietary lipids & Rumen lipids & \\
\hline & Alfalfa meal with $10 \%$ & 100.5 & $47 \cdot 3$ & \\
\hline 2 & cottonseed oil added & & $40 \cdot 5$ & \\
\hline Goat: I & $\begin{array}{l}\text { Alfalfa meal with } 10 \% \\
\text { linseed oil added }\end{array}$ & $180 \cdot 6$ & $49^{\circ} \circ$ & $\begin{array}{l}\text { Reiser \& Reddy } \\
\quad(\text { I956) }\end{array}$ \\
\hline Sheep & Clover-rich pasture & $192 \cdot 2^{*}$ & $33^{*} 7^{*}$ & Shorland et al. (1955) \\
\hline Sheep & $\begin{array}{l}\text { Hay and concentrates with } \\
4 \circ \mathrm{g} \text { linseed oil/day added }\end{array}$ & $18 I \cdot 3$ & $76 \cdot 3 \dagger$ & $\begin{array}{l}\text { Garton, Hobson \& } \\
\text { Lough (1958) }\end{array}$ \\
\hline
\end{tabular}

* Calculated from the determined fatty-acid composition.

$\uparrow$ Isolated in the form of free fatty acids, accounting for $92 \%$ of the lipid present (see text). 
over $50 \%$ of that in pasture glycerides being converted into stearic acid; in addition, trans-isomers of unsaturated acids were formed in the rumen. This latter observation substantiated an earlier report (Hartman, Shorland \& McDonald, I954) that trans-unsaturated fatty acids are characteristic of the depot fats of ruminant herbivores and that they were present to the extent of about $9 \%$ in the lipids of the rumen contents of sheep, though none could be detected in the lipids of the ingested pasture.

In more detailed in vitro studies Shorland, Weenink, Johns \& McDonald (I957) incubated oleic, linoleic and linolenic acids (cis-isomers of plant origin) singly with sheep rumen contents for 2 days in an anaerobic atmosphere and studied the resulting products of hydrogenation. With each, about $20 \%$ of the original acid was fully saturated to yield stearic acid, and trans-isomers accounted for 17,48 and $60 \%$ respectively of the oleic, linoleic and linolenic acids. In addition, from both linoleic and linolenic acids positional isomers of the former were produced which included isomers in which the double bonds were in the conjugated state (i.e. $-\mathrm{CH}=\mathrm{CH}$ $-\mathrm{CH}=\mathrm{CH}-$ ) and which were apparently resistant to further hydrogenation. A further illustration of the resistance of conjugated double bonds to hydrogenation was the finding that the amount of carotene present in the rumen contents did not change during these incubation experiments.

As is discussed in some detail by Shorland et al. (1957), it is interesting to note that the positional and geometrical isomers that result from the microbial hydrogenation of unsaturated fatty acids are very similar to those which are produced during the industrial hardening of lipids by hydrogenation.

Hydrolysis of triglycerides. In experiments in which linseed oil and tung oil were incubated with the rumen contents of sheep Garton et al. (1958) found that not only did hydrogenation take place, as indicated by a considerable fall in the iodine value of the lipid, but that lipolysis had also occurred, more than $75 \%$ of the total lipid recovered at the end of the incubation being in the form of free higher fatty acids and, of the lipids initally present in the rumen contents alone, free higher fatty acids represented $50-60 \%$ of the total amount.

Further experiments were carried out in which linseed oil was incubated anaerobically with rumen contents obtained from a fistulated sheep $4 \mathrm{~h}$ after the last feed of

Table 3. Amounts and iodine values of free higher fatty acids found after incubation of sheep rumen contents, with and without the addition of linseed oil, at $37^{\circ}$ for $24 h$ (Garton et al. 1958)

(Each flask contained roo $\mathrm{ml}$ rumen contents)

Flask
no.
$\left.\begin{array}{l}1 \\ 2 \\ 3 \\ 4\end{array}\right\}$

Treatment before
incubation
None
Heated at $90^{\circ}$
for I $h$

\begin{tabular}{l}
\multicolumn{1}{c}{ Addition } \\
None \\
Linseed oil $(\mathrm{I} \cdot \mathrm{g})$ \\
None \\
Linseed oil $(\mathrm{I} \cdot \mathrm{g})$
\end{tabular}

$\overbrace{\begin{array}{c}\text { Weight } \\ (\mathrm{mg})\end{array}}^{\text {Free fatty acids }}$


hay and concentrates and with the same rumen contents previously heated in a boiling water-bath. The results of one such experiment are given in Table 3 .

After allowance for the difference between the amounts of free fatty acids in an unheated and heated flask, calculations showed that about $60 \%$ of the esterified fatty-acid residues was liberated from the oil in the unheated flask. No lipolysis was observed in the heated one, the slight difference between the amounts of fatty acids recovered from that flask and the one without linseed oil being due to the traces of free acid orginally present in the oil. Extensive lipolysis of ingested glycerides in the intact sheep was found on examination of the rumen contents of an animal that had been fed for several months on a diet of hay and concentrates to which $40 \mathrm{~g}$ linseed oil were added daily. At slaughter, $7 \mathrm{~h}$ after the last feed, $92 \%$ of the lipids in the rumen consisted of free, partially hydrogenated, higher fatty acids (see Table I).

No lipolytic activity could be detected in the mixed saliva of adult sheep and it is presumed that the rumen micro-organisms are responsible for the production of a potent lipase.

Fate of glycerol. The finding that triglycerides can be almost completely hydrolysed in the rumen raises the question of the fate of the glycerol formed.

The fermentation of glycerol by rumen contents of sheep was studied in vivo and in vitro by Johns (I953) who reported that it gave rise almost entirely to propionic acid, thus explaining its antiketogenic effect in the treatment of 'sleepy sickness' in ewes. The fermentation of glycerol was, however, slow compared with that of glucose, and in the living animal almost $50 \%$ of a dose of $180 \mathrm{~g}$ was still present in the rumen $7 \mathrm{~h}$ after it had been administered; similar results were obtained in vitro. Johns suggests that the unfermented glycerol may be absorbed directly through the rumen wall or, if not, then lower down the alimentary tract.

In preliminary studies at the Rowett Research Institute (P. N. Hobson, G. A. Garton \& A. K. Lough, unpublished) we have observed a somewhat more rapid rate of fermentation than that found by Johns (I953). In experiments similar to those outlined in Table 3 we were unable to detect significant amounts of free glycerol in sheep rumen contents or in the medium resulting from the incubation of the rumen contents with linseed oil and, further, when glycerol itself $(0.5 \mathrm{~g})$ was incubated with rumen contents ( $100 \mathrm{ml}$ ) no glycerol apparently remained after $24 \mathrm{~h}$ incubation. This disappearance of glycerol was studied in further experiments and it was found that after $4 \mathrm{~h}$ incubation $50 \%$ of the added glycerol was present, after $9 \mathrm{~h} \mathrm{I} 3 \%$ was left and after $23 \mathrm{~h}$ only $\mathrm{I} \%$ remained. The simultaneous production of volatile fatty acid (calculated as propionic acid) did not account for more than about $50 \%$ of the glycerol that disappeared.

\section{Lipids of rumen micro-organisms}

The lipids present in the rumen micro-organisms constitute a very small fraction of the total lipids in the rumen contents as a whole and hence the bacteria and protozoa which pass down the digestive tract along with the ingesta do not provide quantitatively significant amounts of lipid to the host animal. 
However, in view of the increasing use of solvent-extracted feeding-stuffs and the possible need of ruminants for essential fatty acids, Cunningham \& Loosli (1954) raised the question of whether or not such acids are furnished by the lipids of the rumen bacteria.

Concurrently with studies in which Cunningham \& Loosli (I954) were unable to demonstrate synthesis of linoleic or linolenic acid by bovine rumen bacteria in vitro, Garton \& Oxford (1955) undertook an examination of the lipids present in bacteria of the rumen fluid of mature, hay-fed sheep. The lipids, which accounted for $9 \%$ of the dry weight of the organisms, comprised $39.2 \%$ of acetone-insoluble material (phospholipids) and $48 \cdot 3 \%$ of acetone-soluble lipids, the remainder consisting essentially of free, lower, steam-volatile fatty acids (almost certainly fermentation products). The proportion of acetone-soluble lipids was made up of neutral (glyceride) fat $38 \cdot 2 \%$ and unsaponifiable matter $10.1 \%$; the latter consisted largely of sterol-like material but no cholesterol was detected. The fatty acids of both the glycerides and the phospholipids were fairly saturated, having iodine values of 23.8 and 29.3 respectively; none of the unsaturation in either was due to linoleic or linolenic acids.

Thus it appears that if the ruminant requires essential fatty acids they must be of dietary origin and must also escape saturation in the rumen; that some almost certainly do reach the intestine unaffected by hydrogenation is inferred from the occurrence of cis-cis-linoleic acid in cow's-milk fat (White \& Brown, r949) and the presence in the plasma of pasture-fed cows of cholesterol esters containing considerable amounts of $\mathrm{C}_{18}$ polyethenoid acids, apparently largely as cis-isomers (Lough \& Garton, 1957).

\section{REFERENCES}

Cunningham, H. M. \& Loosli, J. K. (1954). 7. Anim. Sci. 13, 265.

Garton, G. A. \& Oxford, A. E. (1955). F. Sci. Fd Agric. 6, 142.

Garton, G. A., Hobson, P. N. \& Lough, A. K. (1958). Nature, Lond., r82, 15 II.

Hartman, L., Shorland, F. B. \& McDonald, I. R. C. (1954). Nature, Lond., 174, I85.

Hilditch, T. P. (1956). The Chemical Constitution of Natural Fats, 3rd ed. revised, p. 152. London: Chapman and Hall Ltd.

Johns, A. T. (1953). N.Z. F. Sci. Tech. 35, sect. A, p. 262.

Lough, A. K. \& Garton, G. A. (1957). Biochem. F. 67, 345.

Reiser, R. (1951). Fed. Proc. 10, 236.

Reiser, R. \& Reddy, H. G. R. (1956). F. Amer. Oil Chem. Soc. 33, 55.

Shorland, F. B. (1944). Nature, Lond., r53, I68.

Shorland, F. B. (1955). In Progress in the Chemistry of Fats and Other Lipids. Vol. 3, chapter 8. [R. T. Holman, W. D. Lundberg and T. Malkin, editors.] London and New York: Pergamon Press.

Shorland, F, B., Weenink, R. O. \& Johns, A. T. (I955). Nature, Lond., I75, i 129.

Shorland, F. B., Weenink, R. O., Johns, A. T. \& McDonald, I. R. C. (I957). Biochem. F. 67, 328.

White, M. F. \& Brown, J. B. (1949). Y. Amer. Oil Chem. Soc. 26, 385.

Ward, R. M. \& Allen, R. S. (1957). F. agric. Fd Chem. 5, 765.

Willey, N. B., Riggs, J. K., Colby, R. W., Butler, O. D. Jr. \& Reiser, R. (1952). J. Anim. Sci. 11, 705.

\section{Milk composition in relation to rumen metabolism}

\section{By J. A. F. Rook, National Institute for Research in Dairying, Shinfield, Reading}

For many years, the view was held that the type and amount of food offered to a cow, though it had a marked effect on milk yield, had a negligible effect on the fat and 